\title{
Augmenting Entrepreneurship among Management Graduates
}

\author{
Dr.V. Dhamodharan and M. Sundari
}

\begin{abstract}
Entrepreneurs are simply those who understand that there is little difference between obstacle and opportunity and are able to turn both to their advantage."
\end{abstract}

Keywords--- Entrepreneurship, Management, Business, Opportunities, Development

\section{INTRODUCTION}

$\mathrm{A}$ $\mathrm{N}$ entrepreneur is a person who develops a new idea and takes the risk of setting up an enterprise to produce a product or service which satisfies customer needs. All entrepreneurs are business persons, but not all business persons are entrepreneurs. The entrepreneur on the other hand is the business person who is not satisfied with his/her performance and therefore always finds ways to improve and grow.

It is important for us to note that a successful entrepreneur possesses the following characteristics:

- Initiative

- Opportunity seeking

- Persistence

- Information seeking

- Demand for quality and efficiency

- Risk taking

- Goal setting

- Commitment to work

- Systematic planning and monitoring

- Persuasion and networking

- Independence and self confidence

All the above qualities are likely to be there in a management student too

\section{REASONS TO PROMOTE ENTREPRENEURSHIP AMONG} MANAGEMENT GRADUATES

- To improve backwardness of the people.

- Economic development of the region.

- To analyse resource utilization.

- Proper utilization of human potentiality.

- Special attention to take up new activities.

Dr.V. Dhamodharan, Assistant Professor, Department of Business Administration, Government Arts College (Autonomous), Nandanam, Chennai.

M. Sundari, Research Scholar, Bharathiar University, Coimbatore., Assistant Professor, Saveetha School of Management, Saveetha University, Chennai-77.E-mail: sundaris@hotmail.com
- To create self-employment and generation of employment opportunity.

- Eradication of regional imbalances.

- Better economic gain.

The economic activity with a profit motive can only be generated by promoting an attitude towards entrepreneurship. The renewed interest in the development of entrepreneurship to take up new venture should emphasize on the integrated approach. The developments of entrepreneurship will optimize the use of the unexploited resources, generate selfemployment and a self sufficient economy.

Entrepreneurship should be promoted through the following initiatives:

- Management Institutes

- Financial Institutes

- Government

- NGOs

- Corporates

- Business Magnets

The young management graduates should be motivated to come out with determination to do something of their own and also to contribute to the national income and wealth in the economy. If the country wants to achieve the growth at the grass root level, through social justice and the crimination of poverty, it will have to provide institutional support and structural changes in organization of financial institutions to promote entrepreneurship development.

\section{REASONS TO PROMOTE ENTREPRENEURSHIP AMONG MANAGEMENT STUDENTS'}

- To improve backwardness of the people.

- Economic development of the region.

- To analyse resource utilization.

- Proper utilization of human potentiality.

- Special attention to take up new activities.

- To create self-employment and generation of employment opportunity.

- Eradication of regional imbalances.

- Better economic gain.

The economic activity with a profit motive can only be generated by promoting an attitude towards entrepreneurship. The renewed interest in the development of entrepreneurship to take up new venture should emphasize on the integrated approach. The developments of entrepreneurship will optimize the use of the unexploited resources, generate selfemployment and a self sufficient economy. 
Management students' should be motivated to come out with determination to do something of their own and also to contribute to the national income and wealth in the economy. If the country wants to achieve the growth at the grass root level, through social justice and the crimination of poverty, it will have to provide institutional support and structural changes in organization of financial institutions to promote entrepreneurship development. Industrial development in any region is the outcome of purposeful human activity and entrepreneurial thrust.

The entrepreneurial motivation is one of the most important factors which accelerates the pace of economic development by bringing the people to undertake risk bearing activities. In many of the developing countries a lot of attention is being paid to the development of entrepreneurship because it is not the proprietary quality of any caste and community.

\section{BUSINESS IDEAS \& BUSINESS OPPORTUNITIES}

- Entrepreneurial businesses come in all shapes and sizes. With only a few exceptions, if a big company can do it, so can a small one. World of possibilities include,

- retail,

- direct sales,

- Franchises

- Home-Based Business

- Network Marketing and a wide range of service businesses.

A. Developing Entrepreneurship can be done through Following Ways

- Begin with a clear understanding of the feasibility and objectives of the programme, focusing on the development of ventures with the potential for rapid growth.

- Develop criteria to select carefully the target group that is the most entrepreneurial.

- Identify the market through an intensive preparation process, searching for innovation and growth potential.

- Provide support through an independent, privatesector-based organizational structure.

- Decide on a basic methodology that integrates the entrepreneurship development elements with other support and follow-up.

- Create special measures to develop the desired competencies of trainers and facilitators.

- Launch a pilot entrepreneurship development programme and expand to a national network as warranted.

- Internalize the entrepreneurship development support system so that it has the momentum and capability to continue and expand through local efforts.

- Successful entrepreneurship also depends supportive and coordinated government policies.

\section{Charms of BeING AN ENTREPRENEUR}

The most exciting part of Entrepreneurship is that one is his own master. When one is an employee, they should work for others according to their plans, whims and finances. In an Entrepreneurship, setting the goal, planning the action and reaping the satisfaction and rewards are achieved by the entrepreneur.

Why should a management student become an Entrepreneur?

- To become his own boss and boss to other people and make decisions that are crucial to the business success or failure.

- To make money for himself rather than for someone else.

- To participate in every aspect of running a business and learn and gain experience in a variety of disciplines.

- To have the chance to work directly with his customers.

- To have the personal satisfaction of creating and running a successful business.

- To be able to work in a field of area that you really enjoy.

- To have the chance to build retirement value.

\section{A. Rewards for an Entrepreneur}

1. Freedom to work.

2. Satisfaction of being own boss.

3. Power to do things as he likes.

4. Rewards of ownership and retirement assurance.

5. Respect of family and friends.

\section{ROLE OF ENTREPRENEURSHIP IN ECONOMIC DEVELOPMENT}

Economic development essentially means a process of upward change whereby the real per capita income of a country increases for a long period of time. The crucial role played by the entrepreneurs in the western countries has made the people of underdeveloped countries conscious of the significance of entrepreneurship in economic development. After the Independence, India has realized that, for achieving the goal of economic development, it is necessary to increase the entrepreneurship both qualitatively and quantitatively in the country.

Parson and Smelter described entrepreneurship as one of the two necessary conditions for economic development, the other being increased output of capital. Y.A. Say high describes entrepreneurship as a necessary dynamic force for economic development. The important role that an entrepreneurship plays in the economic development of an economy can be put in a more systematic manner as follows:

1. Entrepreneurship promotes capital formation by mobilizing the idle saving of the public.

2. It provides immediate large-scale employment. Thus it helps to reduce unemployment in the country.

3. It provides balanced regional development. 
4. It helps reduce the concentration of economic power.

5. It stimulates the equitable redistribution of wealth, income and even political power in the interest of the country.

6. It encourages effective resources mobilization of capital and skill which might otherwise remain unutilized and idle.

7. It also induces backward and forward linkages which stimulated the process of economic development in the country.

8. It promotes country's export trade i.e. an important ingredient for economic development.

\section{CONCLUSION}

An entrepreneur is a person who tries to create something new, organizes production and undertakes risks and handles economic uncertainty involved in enterprise.

Entrepreneur should be a risk bearer

Entrepreneur - an organizer

Entrepreneur - an innovator

Management graduates need to be equipped and be motivated for being the same.

Entrepreneurship needs people with risk-taking attitude. Apart from money, other fringe benefits like passion and dreams matter a lot. Once such people are identified from the management institutions, then promoting this behavior to others becomes very easy. The purpose of entrepreneurship revolution in the country is to create jobs than to seek jobs.

Institutions make a country great and individuals play their role in the desirable functioning of institutions. India needs quality institutions in great numbers which can evolve markets or intensify competition. In this connection, Management institutes should take the lead to promote entrepreneurship through their students'. 